\title{
Scanning Electron Microscopic Study of Aplectana Duttaphryni Sou, Sow and Nandi, 2014 from A New Frog Host, Fejervarya limnocharis in West Bengal
}

\author{
Siddharthasankar Banerjee ${ }^{1}$ and Sujan Kumar Sou ${ }^{2}$ \\ ${ }^{1}$ Department of Zoology, Burdwan Raj College, Post-Rajbati, \\ Dist- Purba Bardhaman, Pin-713104, West Bengal, India. \\ ${ }^{2}$ Department of Zoology, Kulti College, Post-Kulti, Dist-Paschim Bardhaman, \\ Pin-713343, West Bengal, India. \\ http://dx.doi.org/10.13005/bbra/2933
}

(Received: 04 July 2021; accepted: 17 September 2021)

\begin{abstract}
Aplectana duttaphryni Sou, Sow and Nandi, 2014 was first reported in Kulti, Asansol coal-mine region, West Bengal from a toad, Duttaphrynus melanostictus (Schneider, 1899) only using light microscope. Present article describes, A. duttaphryni in details collected from the rectum of an anuran frog, Fejervarya limnocharis (Gravenhorst, 1829) in Birbhum district, West Bengal. Aplectana duttaphryni is reported for the first time from Birbhum district, West Bengal. The parasites identified by its lanceolate shaped gubernaculum, presence of 1 pair of similar and equal spicules and also with the presence of 3 pairs of preanal papillae, 2 pairs of adanal papillae, 13 pairs of postanal papillae and single papillae on the upper lip of anus. In the present study, Birbhum district recorded as new geographical locality and F. limnocharis recorded as a new host.
\end{abstract}

Keywords: Aplectana duttaphryni; Grass Frog; Nematoda; Parasites.

Fejervarya limnocharis (Gravenhorst, 1829 ) is a frog species (Amphibia, Anura, Dicroglossidae) and are commonly found in South East Asia and these frogs are popularly known as rice field frog or Asian grass frog. They are generally available in cultivated fields, ponds and also found around slow-flowing water streams ${ }^{4}$. The frogs are grey brown in colour, sometimes a $\mathrm{V}$-shaped dark mark between eyes is found and a yellow vertebral stripe mostly present; throat is mottled with brown in male. These frogs are eating small insects such as flies and moths, as well as snails, slugs and worms ${ }^{4}$. In the field it can be identified by its relatively pointed snout and flattened head. The toes of the frog are long. The frog is typically brownish, with darker blotches, sometimes with a greenish or reddish tinge. A vertebral stripe may sometimes be present; this may be cream in colour, or sometimes greenish ${ }^{1,2,3}$. Dutta and Mukhopadhyay ${ }^{4}$, reported the presence of nine anuran species from Durgapur region, West Bengal, and $F$. limonocharis is one of them. But there was no such reports are available in Birbhum district on amphibians.

In this survey, seven male and nine female nematode parasites were collected from two $F$. limnocharis from Dubrajpur region, Birbhum, West Bengal. The recovered nematodes were identified as 
Aplectana duttaphryni ${ }^{5}$. As per our best knowledge, this is the first scanning electron microscopic work of A. duttaphryni from South Asia as well as from India. Till now, five species of Aplectana from the Indian Subcontinent are $A$. macintoshii ${ }^{6}, A$. duttaphryni ${ }^{5}$, A. dubrajpuri ${ }^{7}$, A. hoplobatrachusia ${ }^{8}$ and $A$. akhrami ${ }^{9}$ in Pakistan ${ }^{5,6,7,8,9,10}$. Recently Sou and Banerjee ${ }^{11}$, reported a new species, Aplectana sriniketanensis Sou and Banerjee, 2020 from West Bengal. Thus, now 57 species of Aplectana have been reported from different biogeographical regions. Among them only five species Aplectana reported from India and seven species from Oriental region (Table: 1) are considered now valid $^{11}$.

\section{MATERIALS AND METHODS}

Two grass frogs, F. limnocharis were brought to the laboratory of the Department of Zoology, Kulti College during March, 2021 from Dubrajpur town $\left(23.7946^{\circ} \mathrm{N}, 87.3761^{\circ} \mathrm{E}\right)$, Birbhum, West Bengal and were subsequently dissected and examined for any parasitic infection. Seven males and nine female nematodes were collected from the two said frogs. Recovered parasites were clean using normal saline water and stored in $70 \%$ alcohol after killing with the same solution. $5 \%$ glycerine was used for light microscopic study. The specimens for scanning electron microscopic (SEM) study, were dried after post-fixation with $2 \%$ osmium tetroxide, then transferred to isoamyl acetate (100\%), coated with gold and microphotographs were taken in a Hitachi S-530 (Japan) at a resolution of 50 ú and operating at an accelerating voltage of $15 \mathrm{kV}$. For helminthological records, nematode specimens have been deposited in the Parasitology Research Laboratory, The University of Burdwan, Purba Bardhaman, W.B. India (Regn. BUPL-170). During measurement, values were taken in millimetres (mm).

\section{Observation}

The collected nematodes were identified as Aplectana duttaphryni ${ }^{5}$. During this study, present nematodes were also compared with the original descriptions of Sou et. al. ${ }^{5}$ (Holotype: Regn. No. BUPL-149A; Allotype: Regn. No. BUPL-149B and Paratypes: Regn. No. BUPL149C) and in the present article new morphological features are included. The aim of the present study is to provide a detailed general morphometry and also the pattern of distribution of caudal papillae of $A$. duttaphryni from a new frog host.

\section{RESULTS}

Aplectana duttaphryni Sou, Sow and Nandi, 2014 (Figs. 2a-i, Figs. 3a-g) (Nematoda: Cosmocercidae) Host: Fejervarya limnocharis (Gravenhorst, 1829) Location of Nematode Parasite: Rectum

Locality: Dubrajpur town, Birbhum district, W.B, India

Latitude and Longitude: $23.7946^{\circ} \mathrm{N}, 87.3761^{\circ} \mathrm{E}$

\section{General Description}

Small nematodes and whitish in colour. Both ends of the body pointed. Cuticular striations prominent. Lateral alae just started anterior to the nerve ring upto the anal area. Somatic papillae numerous in four regular submedian arrangements. Mouth (Fig.2c, d) with three lips. One dorsal lip and two ventro-lateral lips present. Triangular mouth (Fig.3a, b) opening with cuticularised margin as seen in scanning electron microscopic
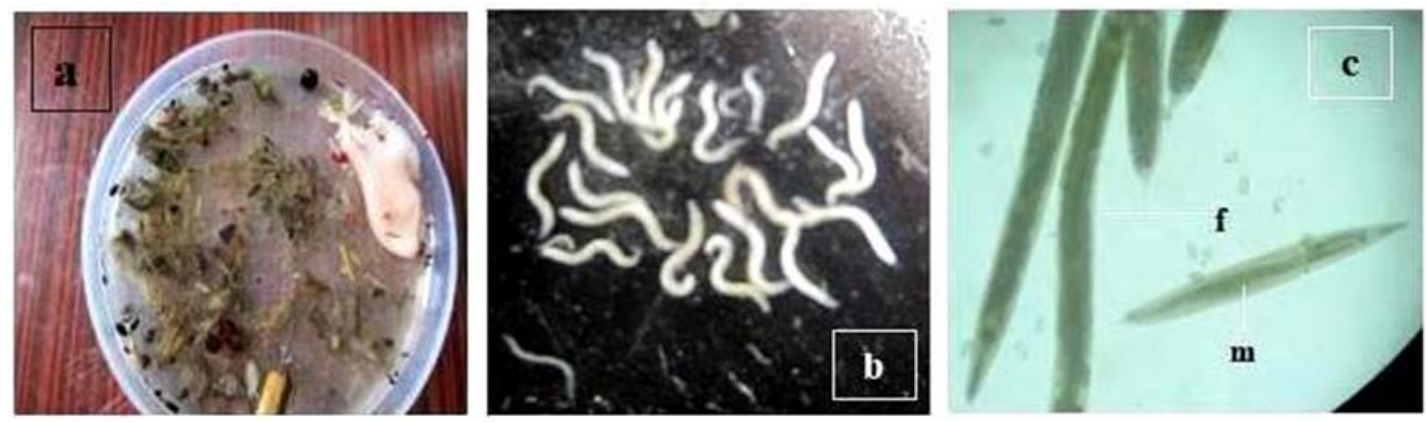

Fig. 1. Photographs of the collected nematodes. a) Ingested food materials of the host (stomach). b) Collected adult nematodes. c) Enlarged view of adult nematodes (f-female, m-male) 
study. Cephalic papillae (Fig.3a) knob-like with ring like base. Oesophageal region divided into a short pharynx, cylindrical corpus ending with an oesophageal bulb. Nerve ring located at the middle portion of the corpus. Excretory pore situated slightly anterior extremity to the oesophageal bulb.

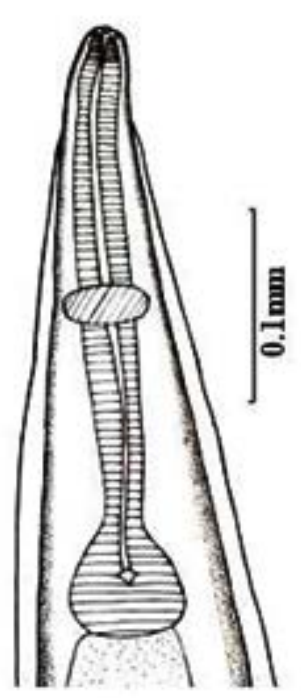

a

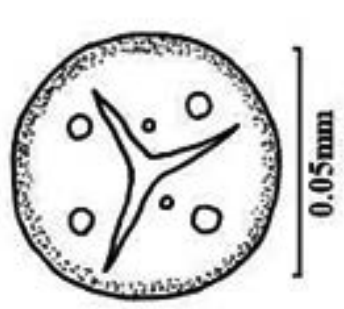

d

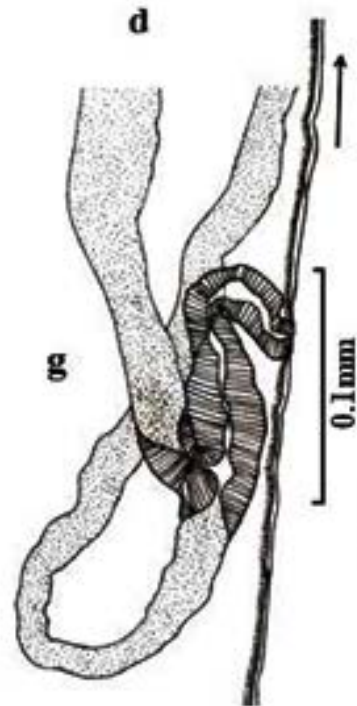

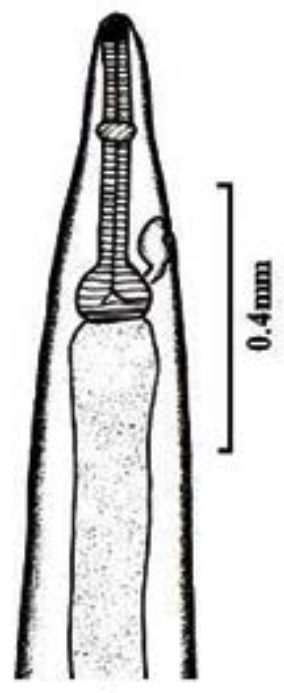

b

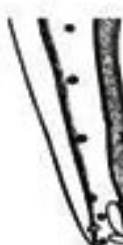

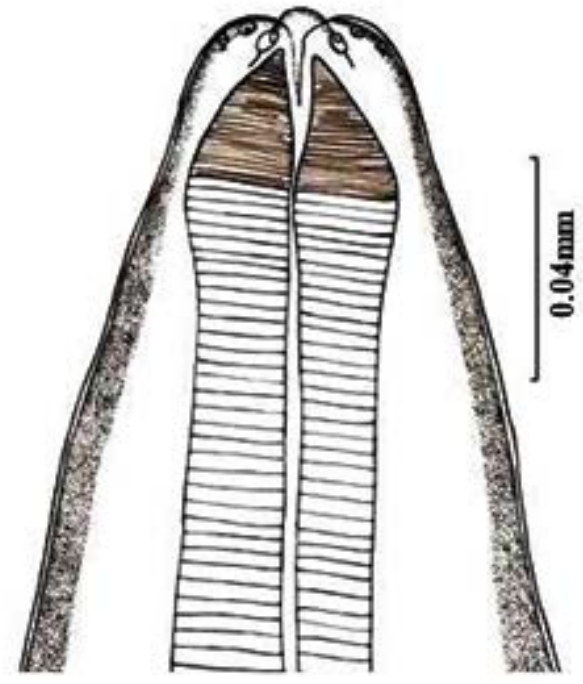

c

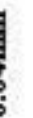

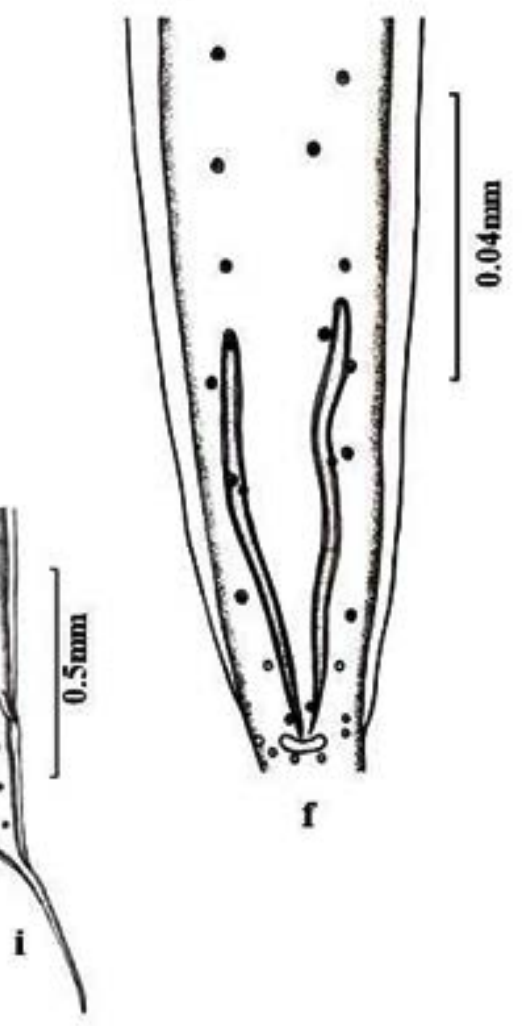

i

Fig. 2. a) Cephalic region of female, ventral view. b) Cephalic region of female, lateral view. c) Expanded form of cephalic end of a male, dorsal view. d) Head region (female). e) Ventral view of caudal end in male. f) Ventral view of male showing the distribution of somatic papillae. g) Vulva of female, arrow points towards cephalic ends, lateral view. h) Structure of egg. i) Lateral view of caudal end in female 
Cervical papillae situated below the nerve ring. In SEM micrograph, the excretory pore (Fig.3c, d) seen to be a transverse slit-like structure.

Male (Based on six specimens)

Length $2.40 \times 2.80$, width at mid body $0.26 \times 0.32$. Oesophagus $0.50 \times 0.57$ long, pharyngeal portion $0.08 \times 0.11 \&$ width $0.07 \times 0.08$, corpus $0.30 \times 0.32$ long $\&$ width $0.08 \times 0.09$. oesophageal bulb $0.12 \times 0.14$ long and $0.10 \times 0.11$ wide. Nerve ring $0.18 \times 0.20$ from anterior end. Excretory pore (Fig.2b) $0.32 \times 0.34$ from anterior end. Cervical papillae $0.23 \times 0.24$ from anterior end. Tail (Fig.2e)
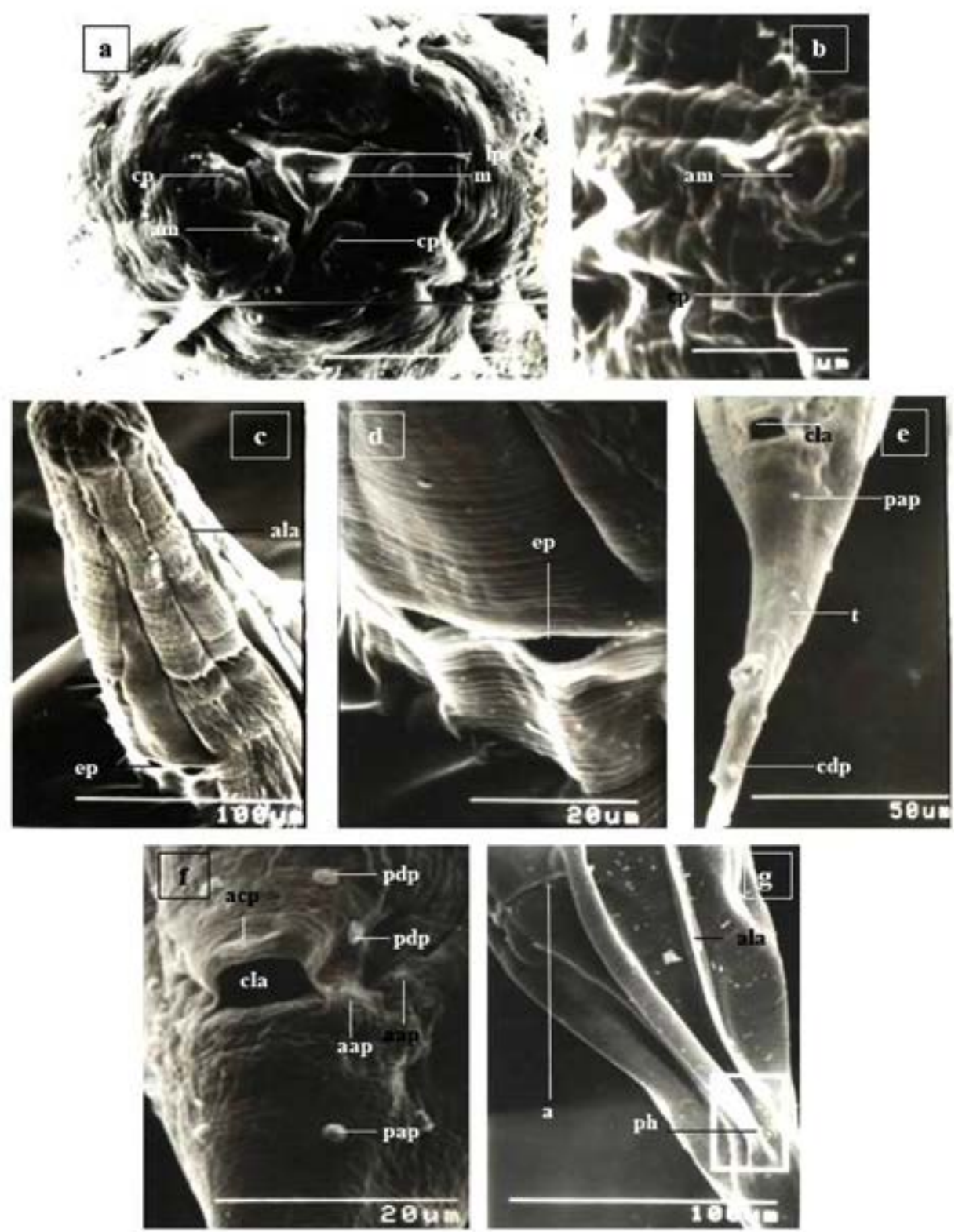

Fig. 3. Scanning electron micrograph- a) Enface view of cephalic end in female. b) Expanded view of head shows amphid and cephalic papillae. c) Cephalic end of female showing excretory pore, lateral view. d) Enlarged view of excretory pore. e) Ventral view of caudal end in male. f) Expanded ventral view of cloacal part in male. g) Lateral view of caudal end in female. (Abbreviations used: m-mouth, am-amphid, ep-excretory pore, aap-adcloacal papillae, acp-papilla on the upper lip of cloaca, ala-lateral alae, cdp-caudal papillae, cp-cephalic papillae, lp-lips, pap-post cloacal papillae, cla-cloaca, ph-phasmids, t-tail, a-anus) 


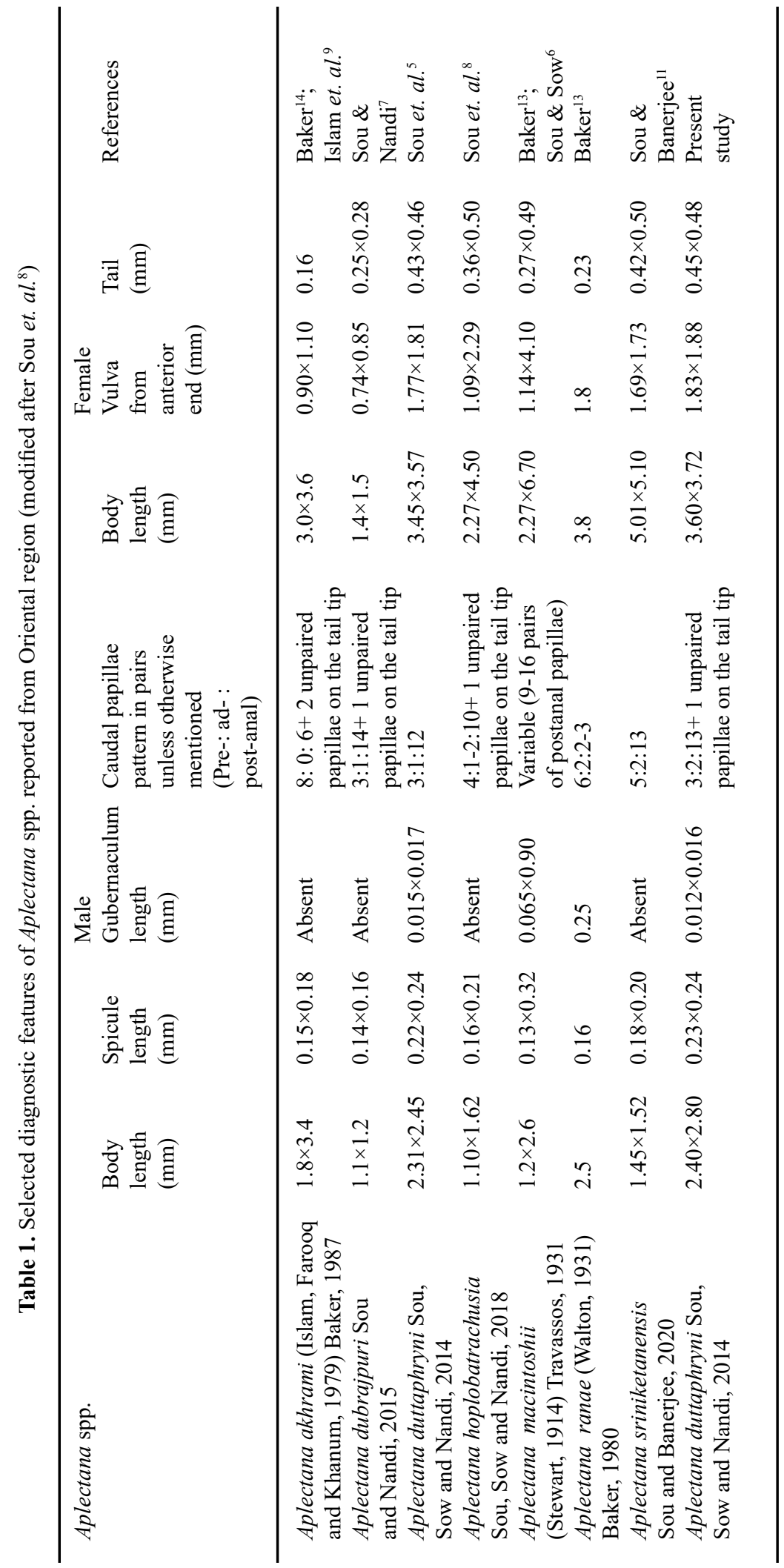


thick anteriorly, rapidly tapers into a spine like structure. Spicules (Fig.2e, f) almost equal and not well developed. Length of left spicule $0.23 \times 0.24$ and right spicule $0.23 \times 0.240$. Gubernaculum (Fig.2e) lanceolate shaped, $0.012 \times 0.016$ long. Phasmids located $0.16 \times 0.18$ from posterior region. Distance of anus (Fig.2e, f) $0.30 \times 0.31$ from posterior end. Somatic papillae (Fig.2f) in eight rows. Ventral surface of the posterior region of the body with 18 pairs of caudal papillae (Fig.2e), among them 3 pairs precloacal, 2 pairs adcloacal, 13 pairs post-cloacal in position and a one papilla on the upper lip of cloacal region. Scanning electron micrographs of the posterior part of male (Fig.3e) showing that cloacal lip (upper part) with a single median unpaired papilla and two small adcloacal papillae. Cloaca (Fig.3f) transversely opened.

\section{Female (Based on eight specimens)}

Body length $3.60 \times 3.72$, maximum width $0.25 \times 0.28$. Oesophagus $0.54 \times 0.58$ long, pharyngeal portion $0.08 \times 0.10$ long and width $0.08 \times 0.10$, corpus $0.33 \times 0.35$ long and width $0.08 \times 0.09$, oesophageal bulb $0.14 \times 0.15$ long and width $0.24 \times 0.26$. Nerve ring (Fig.2a) $0.18 \times 0.20$ from anterior end. Excretory pore (Fig. 2 b) $0.38 \times 0.40$ from anterior end. Cervical papillae $0.21 \times 0.23$ from anterior portion. Distance of anus (Fig. $2 \mathrm{i}$ ) $0.45 \times 0.48$ from posterior part. Tail (Fig.2i) thick anteriorly, rapidly tapers in into a spine like structure. Distance of vulvar (Fig. $2 \mathrm{~g}$ ) opening $1.83 \times 1.88$ from anterior end. Prodelphic reproductive system. Numerous eggs noticed in the uterus. Eggs (Fig.2h) (0.70-0.81 $\mathrm{X}$ 0.59-0.62) oval, thin-shelled and embryonated. Somatic papillae distributed into the tail region in four regular rows. In SEM micrograph, anus (Fig.3g) transverse slit-like structure. Distance of phasmids $0.32 \times 0.33$ from posterior region.

\section{DISCUSSION}

As per our best of knowledge, no redescription of $A$. duttaphryni, as such, is available from West Bengal as well as India. The original species was described by Sou et. al. ${ }^{5}$ from Asansol region of Purba Bardhaman, West Bengal, India. Present nematodes identified as $A$. duttaphryni on the basis of morphological length (Table: 1) and also with presence of lateral alae, somatic papillae, three lips and with a large oesophageal bulb. It also has a short filamentous tail, well distributed caudal papillae, and a well sclerotized gubernaculum. Female reproductive system is prodelphic ${ }^{12}$. In the present study spicules and gubernaculum were separated by dissection of the nematode species. So the collected nematodes were identified as $A$. duttaphryni ${ }^{5}$.

Sou et. al..$^{5}$ studied the morphological structures of $A$. duttaphryni with the help of light microscopy. They described that mouth of nematode is triangular with three simple lips provided with cuticular fold. The scanning electron microscopic studies of present nematodes showing that cuticular fold of the mouth, structure of cephalic papillae and presence of amphids. Distribution pattern of caudal papillae in males are also clearly understandable in this studies. So the present scanning electron microscopy confirms the actual caudal papillae pattern of this species which is different from earlier descriptions of Sou et. al. ${ }^{5}$. The position of phasmids have also been included in the present study.

\section{CONCLUSION}

As per record, Aplectana duttaphryni has been reported only from Asansol region of West Bengal, India. Present paper dealing with the same nematode species but from a different locality with a new host record i.e. Fejervarya limnocharis. There are so many variations recorded during this study, both in morphological features and on general body measurements. Present work therefore, suggests this is due to the intraspecific variations of the nematode species. Finally, it can be concluded that Dubrajpur town of Birbhum district, West Bengal is a new locality for this parasite and at the same time $F$. limnocharis is a new host record since earlier description of $A$. duttaphryni was based on a different host, $D$. melanostictus.

\section{ACKNOWLEDGEMENT}

Thankful acknowledgement is due to The University of Burdwan and Kulti College for giving us laboratory facilities. The authors are thankful to Dr. Anadi Prasad Nandi, Retd. Professor of Zoology, The University of Burdwan for his guidance, encouragement and help during 
this work. Thanks are due to the authorities of the University Science Instrumentation Centre and Central Instrumentation Facilities (USIC \& CIF), The University of Burdwan for affording Scanning Electron Microscope in studying surfacetopography of the present nematodes. The authors thankfully acknowledge the Amphibia Section, Herpetology Division, Zoological Survey of India, Kolkata, West Bengal for identification of hosts.

\section{Conflict of interest}

Authors hereby declared that there is no conflict of interest.

\section{Funding Sources}

No funding agency.

\section{Compliance with ethical standards}

Though there is no ethics committee in our Institutions, snake has been sacrificed for the present study following guidelines of The Committee for the Purpose of Control and Supervision of Experiments on Animals (CPCSEA) formed by the Act of the Indian Parliament.

\section{REFERENCES}

1. Frost D.R. Amphibian Species of the World: an Online Reference. Version 6.0. Electronic Database. American Museum of Natural History, New York, USA. 2020. Available from: http:// research.amnh.org/herpetology/amphibia/ index. html

2. Deuti K. and Bharati-Goswami B.C. A field guide to the amphibians of West Bengal Plains. India. World Wide Fund for Nature-India (Eastern Region), 1995; 53pp.

3. Djong T.H., Islam, M.M., Nishioka, M., Matsui, M., Ota, H., Kuramoto, M., and Sumida, M. Genetic relationships and reproductiveisolation mechanisms among the Fejervarya limnocharis complex from Indonesia (Java) and other Asian countries. Zoological Science, 2007, 24 (4): 360-376. doi: 10.2108/zsj.24.360

4. Dutta S. and Mukhopadhyay S.K. Habitat Preference and Diversity of Anuran in Durgapur, an Industrial City of West Bengal, India. Proceedings of Zoological Society, Kolkata, 2013, 66 (1): 36-40. doi: 10.1007/s12595-0120055-y

5. Sou S.K., Sow, K.K. and Nandi, A.P. On a new species of Aplectana (Nematoda, Cosmocercidae) from Kulti, Burdwan, West Bengal, India. Acta
Parasitologica, 2014, 59 (4): 694-697. doi: https://doi.org/10.2478/s11686-014-0295-2

6. Sou S.K. and Sow K.K. Occurrence of Aplectana macintoshii (Stewart, 1914) Travassos, 1931(Nematoda: Cosmocercidae) in Indian Skipper Frog, Euphlyctis cyanophlyctis (Anura: Dicroglossidae) at Raniganj Town, Paschim Bardhaman, West Bengal. Proceedings of the Zoological Society, Kolkata, 2019, 72 (3): 313317. doi: https://doi.org/10.1007/s12595-0180275-X

7. Sou S.K. and Nandi A.P. Aplectana dubrajpuri sp. nov. (Nematoda: Cosmocercidae) in Hoplobatrachus tigerinus (Anura: Dicroglossidae) from Dubrajpur, Birbhum, West Bengal, India. Acta Parasitologica, 2015, 60 (3): 430-434. doi: https://doi.org/10.1515/ ap-2015-0059

8. 8. Sou S.K., Sow K.K. and Nandi A.P. Aplectana hoplobatrachusia sp. nov. (Nematoda: Cosmocercidae) in Hoplobatrachus crassus (Jerdon, 1853) (Anura: Dicroglossidae) from Birbhum District, West Bengal, India. Zootaxa, 2018, 4472 (1): 194-200. doi: https://doi. org/10.11646/zootaxa.4472.1.12

9. Islam A., Farooq M. And Khanum Z. Two new genera of nematode parasites (Oxyuridae: Oxysomatinae) from toad Bufo andersoni of Pakistan. Pakistan Journal of Zoology, 1979, 11 (1): 69-73

10. Stewart, F.H. Studies in Indian Helminthology. No. I. Records of Indian Museum, 1914, 10 (3): 165-193

11. Sou S.K. and Banerjee S. Description of Aplectana sriniketanensis sp. nov. (Nematoda: Cosmocercidae) from Hoplobatrachus crassus (Anura: Dicroglossidae) from Birbhum District, West Bengal, India. Flora and Fauna, 2020, 26 (1): 134-140. doi: 10.33451/florafauna. v26i1pp134-140

12. Gibbons L.M. Keys to the nematode parasites of vertebrates. Supplementary Volume. CAB International and Natural History Museum, London, 2010; 146 pp.

13. Baker M.R. Revision of old world species of the genus Aplectana Railliet \& Henry, 1916 (Nematoda: Cosmocercidae). Bulletin $d u$ Museum National d'Histoire Naturelle, 1980, 4 (2): 955-998

14. Baker, M.R. (1987) Synopsis of the Nematoda parasitic in amphibians and reptiles. Memorial University of Newfoundland, Occasional Papers in Biology, 1987, (11): 1-325. 